\title{
Chitooligosaccharides from squid pen prepared using different enzymes: characteristics and the effect on quality of surimi gel during refrigerated storage
}

\author{
Avtar Singh ${ }^{1}$, Soottawat Benjakul ${ }^{1 *}$ and Thummanoon Prodpran ${ }^{2}$
}

\begin{abstract}
Chitooligosaccharides (COS) from squid pen produced using amylase, lipase and pepsin were characterized. COS produced by $8 \%(\mathrm{w} / \mathrm{w}$ ) lipase (COS-L) showed the maximum FRAP and ABTS radical scavenging activity than those prepared using other two enzymes. COS-L had the average molecular weight (MW) of $79 \mathrm{kDa}$, intrinsic viscosity of $0.41 \mathrm{dL} / \mathrm{g}$ and water solubility of 49\%. DPPH, ABTS radical scavenging activities, FRAP and ORAC of COS-L were 5.68, $322.68,5.66$ and $42.20 \mu \mathrm{mol} \mathrm{TE} / \mathrm{g}$ sample, respectively. Metal chelating activity was $2.58 \mu \mathrm{mol} \mathrm{EE} / \mathrm{g}$ sample. For antibacterial activity, minimum inhibitory concentration (MIC) and minimum bactericidal concentration (MBC) of COS- $\mathrm{L}$ against the targeted bacteria were in the range of $0.31-4.91 \mathrm{mg} / \mathrm{mL}$ and $0.62-4.91 \mathrm{mg} / \mathrm{mL}$, respectively. Sardine surimi gel added with $1 \%(\mathrm{w} / \mathrm{W})$ COS-L showed the lower PV, TBARS and microbial growth during 10 days of storage at $4^{\circ} \mathrm{C}$. COS-L from squid pen could inhibit lipid oxidation and extend the shelf-life of refrigerated sardine surimi gel.
\end{abstract}

Keywords: Chitosan, Squid pen, Chitooligosaccharide, Sardine surimi, Shelf-life extension

\section{Introduction}

Chitosan is a non-toxic deacetylated chitin, with a variety of applications such as antibacterial, antioxidant and antiaging agents, tissue engineering, cancer diagnosis and drug delivery. It also has ability to enhance the response of antibodies (Elieh-Ali-Komi \& Hamblin 2016). Due to low water solubility, its applications are limited. In general, low MW chitosans $(2.8-87.7 \mathrm{kDa})$ possess much improved solubility and functional activities than high MW chitosan (604-931 kDa) (Laokuldilok et al. 2017). Therefore, physical, chemical or enzymatic methods have been employed to hydrolyze chitosan, in which short chain COS can be produced (II'Ina \& Varlamov 2004). Physical methods such as irradiation and ultrasonication, etc. produced partially depolymerized chitosan but the reduction in MW is restricted (Lodhi et al. 2014). In contrast, chemical hydrolysis is harsh and is uncontrolled to

\footnotetext{
* Correspondence: soottawat.b@psu.ac.th

${ }^{1}$ Department of Food Technology, Faculty of Agro-Industry, Prince of

Songkla University, Hat Yai, Songkhla 90110, Thailand

Full list of author information is available at the end of the article
}

produce the desired COS (Lodhi et al. 2014). Enzymatic hydrolysis has been implemented to manufacture low MW COS with controlled degree of depolymerization (Lee et al. 2008; Lodhi et al. 2014). However, enzymes specific for chitosan degradation such as chitosanase and chitinase are costly and less available. Various hydrolytic enzymes including 10 kinds of glycanases, 21 kinds of proteases, 5 lipases and a tannase from various sources have been employed for hydrolysis of chitosan. Nevertheless, the exact mechanism of hydrolysis of chitosan by those enzymes is still unknown (Mourya et al. 2011). Hence, non-specific enzymes such as amylase, pepsin, pectinase, papain, cellulase and lipase have been used to hydrolyze chitosan for production of COS (Lodhi et al. 2014).

Surimi is concentrated myofibrillar protein obtained from fish mince. It has exceptional textural properties and high nutritional value and can be used for the production of various products (Singh \& Benjakul 2017a). Owing to the overexploitation of lean fish, surimi industry is showing great interest to utilize dark fleshed fish for example sardine, mackerel etc. (Quan \& Benjakul 2017; Singh \& Benjakul 
2017b). Dark flesh of small pelagic fish species mainly has high contents of myoglobin and lipid (Singh \& Benjakul 2018). This leads to the susceptibility of surimi toward lipid oxidation. This can shorten shelf-life caused by off-flavor development in the resulting gel products stored for an extended time (Sae-leaw et al. 2018). A wide range of antioxidants has been included into surimi to tackle this problem. Owing to unhealthy impact of synthetic antioxidants on human health, natural antioxidants have been utilized in foods widely (Sae-leaw et al. 2018).

Chitosan can be also produced from squid pen and it is classified as $\beta$-form (Elieh-Ali-Komi \& Hamblin 2016). Squid pen chitosan can be transformed to COS with antioxidant and antimicrobial activities, which could be used as preservative in some food products, particularly those prone to lipid oxidation or spoilage. Fernandes et al. (2008) documented COS from crab shell (degree of deacetylation; DDA), $80-85 \%$ ) as an antimicrobial agent against common food borne pathogens including Staphylococcus aureus and Escherichia coli in milk and apple juice. Chitosan was fortified into surimi gel to enhance textural properties as well as storage stability of gel kept at refrigerated temperature (Amiza \& Kang 2013; Mao \& Wu 2007). However, no report is available on utilization of COS from squid pen into surimi gel. Therefore, current study can provide useful information for squid processing industry, in which the pen can be fully exploited. Also, COS from squid pen can be used as the natural additive for food applications.

Hence, the purposes of current study were to find the appropriate enzyme for the production of COS and to investigate its impact on storage stability of sardine surimi gel kept at $4{ }^{\circ} \mathrm{C}$.

\section{Materials and methods}

\section{Chemicals, surimi and bacterial strains}

All chemicals were of analytical grade. Amylase, lipase, pepsin, ethylenediaminetetraacetic acid (EDTA), 2,4,6tripyridyltriazine (TPTZ), 2,2diphenyl-1-picrylhydrazyl $(\mathrm{DPPH})$, fluorescein, 2,2'-azobis (2-methylpropionamidine) dihydrochloride (AAPH), 6-hydroxy-2, 5, 7, 8tetramethylchroman-2carboxylic acid (Trolox) and 2, 2azinobis-(3-ethylbenzothiazoline-6-sulfonic acid) diammonium salt (ABTS) were procured from Sigma-Aldrich, Inc. (St. Louis, MO, USA). Tryptic soy broth and tryptic soy agar were obtained from Difco, Le Port de claix, France.

Frozen sardine surimi (AA grade) was bought from Chaichareon Marine Co., Ltd. (Pattani, Thailand). Surimi was stored at $-20^{\circ} \mathrm{C}$ and used within 2 months.

Pseudomonas aeruginosa PSU.SCB.16S.11, Listeria monocytogenes F2365, Vibrio parahaemolyticus PSU.SCB.16S.14, Staphylococcus aureus DMST 4745, Salmonella enterica serovar Enteritidis S5-371 were gifted from Food Safety
Laboratory, Department of Food Technology, Prince of Songkla University, Hat Yai, Thailand.

\section{Preparation of chitooligosaccharide (COS)}

Chitosan was firstly extracted from squid pen as described by Singh et al. (2019a). Degree of deacetylation (DDA), intrinsic viscosity $[\eta]$ and average MW were $87 \%, 3.79 \mathrm{dL} / \mathrm{g}$ and $1.5 \times 10^{5} \mathrm{Da}$, respectively (Singh et al. 2019a). To prepare COS, chitosan (1 g) was dissolved in $1 \%(\mathrm{v} / \mathrm{v})$ acetic acid to get a final concentration of $1 \%(\mathrm{w} / \mathrm{v})$. Final $\mathrm{pH}$ of prepared solution was adjusted to 5 with $6 \mathrm{M} \mathrm{NaOH}$. Amylase, lipase or pepsin were added to chitosan solution at the concentration of $8 \%$ (w/w), which yielded the COS with the highest degree of depolymerization (DDP) and antioxidative activity (based on the preliminary study). Amylase and lipase assisted hydrolysis was carried out at $50^{\circ} \mathrm{C}$ and hydrolysis using pepsin was done at $37^{\circ} \mathrm{C}$ for different times $(0,1,3,6$, $12,24,36,48,60$ and $72 \mathrm{~h}$ ). The hydrolysis was terminated by heating the solution at $95^{\circ} \mathrm{C}$ for $10 \mathrm{~min}$. All the hydrolysates were determined for degree of depolymerization (DDP) by measuring reducing sugar using dinitrosalicylic acid (DNS) method (Miller 1959) in comparison with total sugar content analyzed by the Dubois method (Dubois et al. 1956). In addition, hydrolysates were subjected to determination of ABTS radical scavenging activity and ferric reducing antioxidant power (FRAP) as described by Tongnuanchan et al. (2012).

\section{Characterization of the selected $\cos$}

COS produced by lipase exhibiting the highest antioxidative activity was adjusted to $\mathrm{pH} 7$ using $6 \mathrm{M} \mathrm{NaOH}$ followed by vacuum filtration. The obtained filtrate was subsequently freeze-dried using a freeze-dryer (CoolSafe 55, ScanLaf A/S, Lynge, Denmark). The resultant powder named as 'COS-L' was used for characterization.

\section{Water solubility}

Percent water solubility of COS-L was measured using the method of Laokuldilok et al. (2017).

\section{Intrinsic viscosity}

Intrinsic viscosity $([\eta])$ of COS-L solution was estimated via an Ubbelohde capillary type viscometer as tailored by Yacob et al. (2013).

\section{Viscosity-average molecular weight $\left(\overline{\mathrm{M}}_{\mathrm{v}}\right)$}

Viscosity-average molecular weight $\left(\overline{\mathrm{M}}_{\mathrm{v}}\right)$ was calculated from intrinsic viscosity ([n]) using Mark-HouwinkSakurada equation (Yacob et al. 2013) as follows:

$$
[\eta]=K \bar{M}_{v}^{\alpha}
$$


where $[\eta]=$ intrinsic viscosity, $\mathrm{K}=9.66 \times 10^{-5}$ and $\alpha=0.742$ determined in the solvent at $25^{\circ} \mathrm{C}$ (Yacob et al. 2013).

\section{Antioxidative activities}

FRAP and ABTS radical scavenging activities of COS-L sample were determined as previously described. In addition, DPPH radical scavenging activity was measured using the method of Benjakul et al. (2014) and was expressed as $\mu \mathrm{mol}$ Trolox equivalent (TE)/g sample. Chelating activity against ferrous ion $\left(\mathrm{Fe}^{2+}\right)$ was examined by the method of Benjakul et al. (2014) and was expressed as $\mu$ mol EDTA equivalent (EE)/g sample. Oxygen radical absorbance capacity (ORAC) was measured as tailored by Buamard and Benjakul (2017) and expressed as $\mu \mathrm{mol}$ Trolox equivalent (TE)/g sample.

\section{Bacterial cell suspension and culturing conditions}

Cultures were grown separately for $18 \mathrm{~h}$ in tryptic soy broth (TSB) until the absorbance of wavelength $600 \mathrm{~nm}$ was 0.8 . Afterward, the cultures were mixed with $15 \%$ glycerol and stored at $-80^{\circ} \mathrm{C}$ until use. Before use, firstly cultures were thawed and sub-cultured on tryptic soy agar at $37^{\circ} \mathrm{C}$ for 24 h. Cells were resuspended in TSB and incubated for $4 \mathrm{~h}$ at $37^{\circ} \mathrm{C}$. Then serial dilutions were performed to dilute the cell concentration to $10^{6} \mathrm{CFU} / \mathrm{mL}$.

Minimum inhibitory concentration (MIC) and minimum bactericidal concentration (MBC) of the COS-L were determined against Listeria monocytogenes, Vibrio parahaemolyticus, Pseudomonas aeruginosa, Staphylococcus aureus and Salmonella enterica as per the method of Olatunde et al. (2018).

Impact of the COS-L on storage stability of sardine surimi gel during refrigerated storage

\section{Surimi gel preparation}

Frozen surimi was chopped into small cubes $(1 \mathrm{~cm})$ with electric saw and tempered under tap water to attain core temperature of surimi to $4{ }^{\circ} \mathrm{C}$. Surimi was blended using a blender (National Model MK-5080 M, Selangor, Malaysia) for $1 \mathrm{~min}$ followed by the addition of $2.5 \%$ salt. COS-L was subsequently added into surimi paste to obtain the final concentration of $1 \%$ and the final moisture content was brought to $80 \%$ with distilled water. The mixture was chopped for $2 \mathrm{~min}$. The temperature of surimi paste during blending was maintained below $7{ }^{\circ} \mathrm{C}$. The paste was stuffed into a polyvinylidine chloride casing with a diameter of $2.5 \mathrm{~cm}$, and both ends were closed tightly. Gels were prepared by setting/heating at 40 and $90^{\circ} \mathrm{C}$ for 30 and $20 \mathrm{~min}$, respectively. All gels were cooled in iced water for $1 \mathrm{~h}$ and stored at $4{ }^{\circ} \mathrm{C}$ for $18 \mathrm{~h}$. For storage study, gels added without and with COS-L were sealed in a zip lock bag and kept for 10 days at $4{ }^{\circ} \mathrm{C}$. Surimi gels were randomly taken at 0,5 , and 10 days for analyses.

\section{Analyses}

Lipid oxidation Peroxide value (PV) and thiobarbituric acid reactive substances (TBARS) of sardine surimi gel incorporated without and with COS-L (1\%) were measured by the method described by Sae-leaw et al. (2018).

Microbial analysis Spread plate method was conducted for microbiological analyses (Sallam, 2007). Ten grams of gel samples were added into $90 \mathrm{~mL}$ of $0.85 \%(\mathrm{w} / \mathrm{v})$ sterile saline solution (supplemented with $0.1 \%$ peptone) followed by homogenization for $2 \mathrm{~min}$ at $220 \mathrm{rpm}$ using a Stomacher blender (Mode 1400, Seward Ltd. West Sussex, England). Obtained homogenates were serially diluted ten-fold in $0.85 \%$ sterile saline solution containing peptone. Total viable count (TVC), psychrophilic bacterial count (PBC), total fungal count (TFC) and spoilage bacteria count including Pseudomonas, and Enterobacteriaceae were determined (Vanderzant \& Splittstoesser 1995).

\section{Statistical analysis}

All experiments were performed in triplicate. Data were applied to analysis of variance. Comparison of means was done by the Duncan's multiple range tests (Steel \& Torrie 1986). Analysis was achieved using a SPSS package (SPSS 22 for Windows, SPSS Inc., Chicago, IL, USA).

\section{Results and discussion}

Degree of depolymerization and antioxidative activities of COS produced using various enzymes for different hydrolysis times

Degrees of depolymerization (DDP) of chitosan treated with $8 \%$ amylase or $8 \%$ lipase or $8 \%$ pepsin are shown in Fig. 1. Chitosan (time $0 \mathrm{~h}$ ) had DDP of around 7\%, indicating that depolymerization occurred to some degree, particularly during deacetylation at high temperature. For each enzyme used, an increase in DDP was observed with increasing hydrolysis time up to $36 \mathrm{~h}(p<0.05)$. Afterward, no further changes in DDP were attained $(p>0.05)$. This was plausibly due to lowered substrate or decreased enzyme activity due to the prolonged hydrolysis (Rokhati et al. 2013). The highest DDP was observed for COS produced by amylase (12 to 31\%), followed by those produced using lipase ( 15 to $26 \%$ ) and pepsin (12 to 23\%), respectively. DDP of COS produced by amylase was quite high, probably due to the presence of $\beta-1,4$ bond between glucosamine, which was similar to that found in amylose (Rokhati et al. 2013). Pan and Wu (2011) documented the optimum condition for hydrolysis of chitosan from shrimp shell using glucoamylase at $\mathrm{pH} 4.5$ and $55^{\circ} \mathrm{C}$ for $24 \mathrm{~h}$. Optimum hydrolysis of chitosan from shrimp shells was conducted using $\alpha$ amylase ( $\mathrm{pH} 5$; temperature $50^{\circ} \mathrm{C}$ ) for $6 \mathrm{~h}$ (Wu 2011). Lipase and pepsin have also been used for production of 


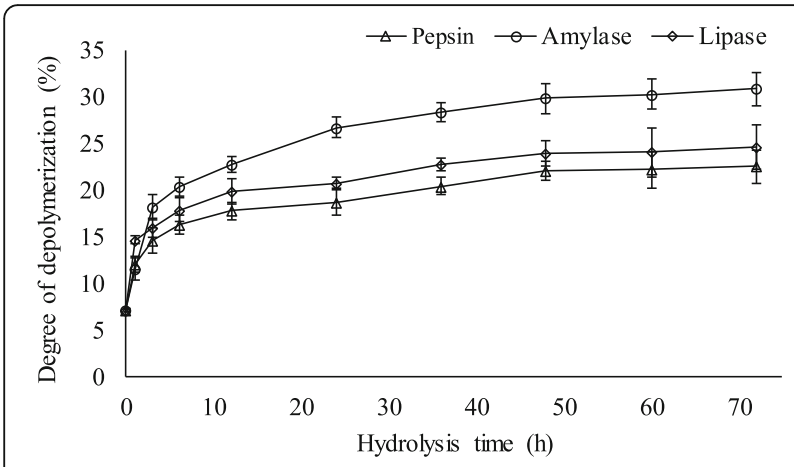

Fig. 1 Degree of depolmerization of chitooligosaccharides (COSs) from squid pen prepared using pepsin, amylase or lipase for diffrent hydrolysis times. Bars represent the standard deviation $(n=3)$. Enzymes at 8\% (w/w) were used

COS from crustacean chitosan (Gohi et al. 2017; Lee et al. 2008; Lee et al. 2007). Lee et al. (2008) observed high DDP of chitosan using lipase at $\mathrm{pH} 4.2-5$. Pepsin is the acidic protease with optimal $\mathrm{pH}$ of $1.5-2.5$ when proteinaceous substrate is used (Piper \& Fenton 1965). Gohi et al. (2017) observed the lower DDP of chitosan at optimum $\mathrm{pH}$ of pepsin (2-3.5). With further increase in $\mathrm{pH}$ to $4-5$, higher DDP was obtained as indicated by the increase in reducing sugar production. Lipase, $\alpha$-amylase and pepsin showed the high hydrolytic activity toward chitosan at $\mathrm{pH}$ around 5. Moreover, at $\mathrm{pH} 5$, positive charge on the chitosan surface was decreased. Under such a condition, the catalytic sites of selected enzymes more likely got in contact with -GlcN-GlcNAc- or -GlcNAc-GlcNAc- linkage, thus favoring the cleavage of chitosan (Gohi et al. 2017). Furthermore, the reduction in viscosity of the chitosan solution was obtained at $\mathrm{pH}$ 5. This could facilitate the mobility of enzymes to cleave chitosan molecules. However, with further increase in $\mathrm{pH}$, chitosan became less soluble due to precipitation, thus lowering the hydrolysis of chitosan. Chitosan has 4 different kinds of glycosidic linkages (Roncal et al. 2007). Enzymes can cleave more than one type of these linkages owing to different affinities of enzyme towards different bondings at different $\mathrm{pHs}$ and DDAs (Lee et al. 2008). This led to varying cleavage rates by different enzymes (Roncal et al. 2007). Therefore, DDP of chitosan generally depends on the type and source of enzyme.

FRAP or ABTS radical scavenging activity of COS produced by various enzymes for different hydrolysis times are presented in Fig. 2a and b, respectively. All COS samples showed the higher FRAP or ABTS radical scavenging activity than chitosan (hydrolysis time: $0 \mathrm{~h})(p<0.05)$. Overall, COS produced by lipase revealed the greater FRAP and ABTS radical scavenging activity, compared to those produced by pepsin and amylase, regardless of hydrolysis time. The highest FRAP was observed in COS produced using lipase at the hydrolysis time of $12 \mathrm{~h}(p<0.05)$. Nevertheless, the maximum ABTS radical scavenging activity was obtained for COS when lipase was utilized for hydrolysis for 12 or $24 \mathrm{~h}(p<0.05)$. Considering time effectiveness, hydrolysis time of $12 \mathrm{~h}$ was selected for the production of COS using lipase, which yielded the resulting COS with high antioxidative activity. Antioxidative activity of chitosan or COS were generally governed by the amino and hydroxyl groups present in pyranose ring. Free radicals can react with the residual free amino groups $\left(\mathrm{NH}_{2}\right)$ of $\mathrm{COS}$ to form stable macromolecule radicals. $\mathrm{NH}_{2}$ groups also can form ammonium groups $\left(\mathrm{NH}_{3}{ }^{+}\right)$by absorbing hydrogen ion from the solution, in which they can work as $\mathrm{H}$-donor to the radicals (Je et al. 2004). Additionally, OH group of COS might react with free radical by the typical $\mathrm{H}$-abstraction reaction (Xie et al. 2001). Antioxidative activity of COS could vary with the degree of deacetylation of chitosan and MW of COS. Lee et al. (2008) reported that lipase could produce both oligomers and monomers of chitosan due to its endo and exo-type specificity towards chitosan. Hence, high ABTS radical scavenging activity and FRAP of COS prepared by lipase might be due to the appropriate size and conformation of COS produced by lipase, in which amino or hydroxyl groups were available and acted as $\mathrm{H}$-donor or radical scavenger.

Since COS produced by lipase at $12 \mathrm{~h}$ of hydrolysis showed the highest antioxidative potential as indicated by FRAP and ABTS radical scavenging assays, it was further freeze-dried and the resultant powder was defined as COS-L.

\section{Characteristics and properties of COS-L Intrinsic viscosity, average MW and water solubility}

Intrinsic viscosity, average MW and water solubility of COS-L are shown in Table 1. Initial intrinsic viscosity and average MW of chitosan (DDA of 87\%) were 3.79 $\mathrm{dL} / \mathrm{g}$ and $1.5 \times 10^{5} \mathrm{Da}$, respectively (Singh et al. 2019a). Both intrinsic viscosity and average MW were decreased to $0.41 \mathrm{dL} / \mathrm{g}$ and $79 \mathrm{kDa}$, respectively after $12 \mathrm{~h}$ hydrolysis by lipase. Reduction in MW and viscosity of chitosan was documented to be governed by the type and source of enzyme used (Il'Ina \& Varlamov 2004). Lipase showed the strong affinity and higher activity to chitosan having the moderate DDA (Lee et al. 2008). Lee et al. (2008) reported that lipase cleaved chitosan with the exo-type mode as well as in end-splitting manner. This resulted in higher reduction in viscosity and MW. COS generally has been reported to have MW higher than $10 \mathrm{kDa}$ (Liaqat \& Eltem 2018). COS produced from commercial chitosan using chitosanase and papain had MWs of 40 and $41 \mathrm{kDa}$, respectively (Laokuldilok et al. 2017; Rahman et al. 2015). Choi et al. (2001) also prepared COS of MW $30 \mathrm{kDa}$ from exoskeletons of marine crustacean chitosan using chitosanase. COS-L showed $49 \%$ solubility in water. Generally, chitosan is not soluble in 
A

- Control $\square$ Pepsin $\square$ Amylase $\square$ Lipase

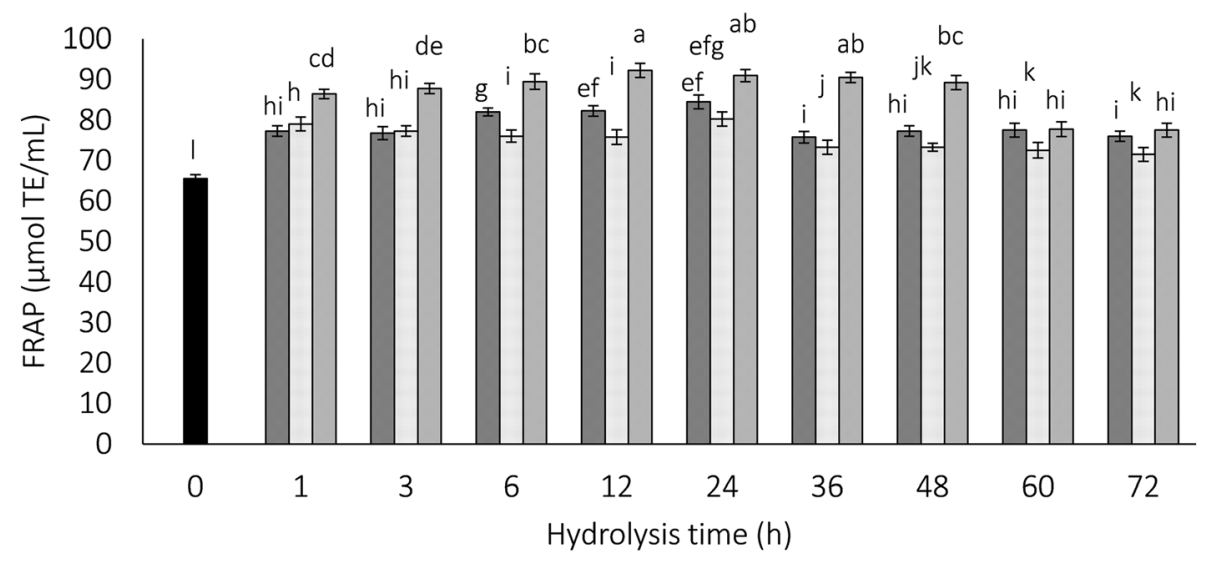

B

- Control $\square$ Pepsin $\square$ Amylase $\square$ Lipase

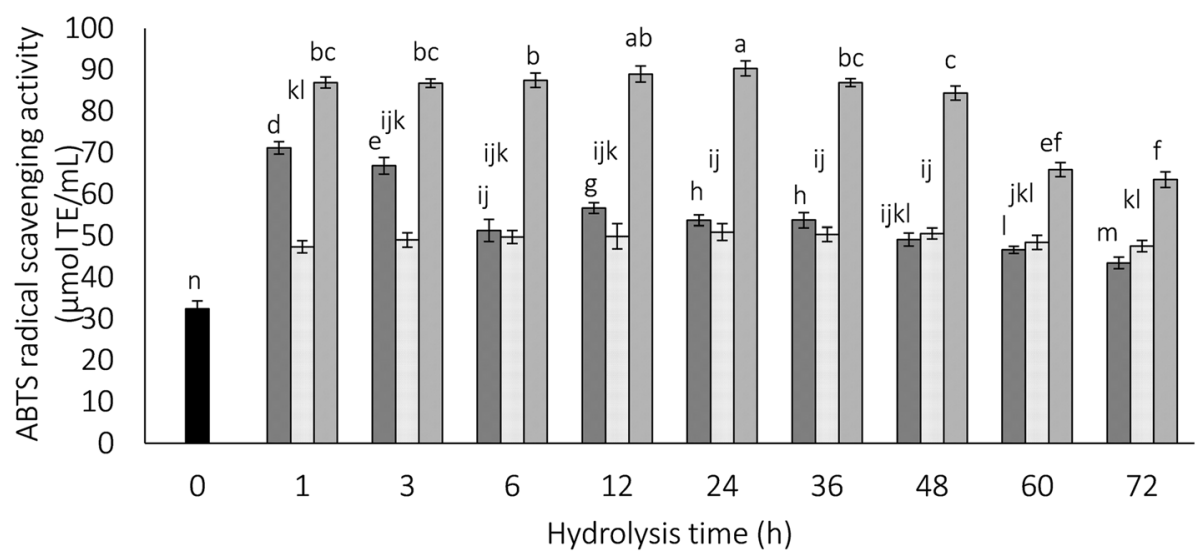

Fig. 2 FRAP (a) and ABTS radical scavenging activity (b) of chitooligosaccharides (COSs) from squid pen prepared using pepsin or amylase or lipase for diffeent hydrolysis times. Bars represent the standard deviation $(n=3)$. Enzymes at $8 \%(w / w)$ were used. Different lowercase letters on the bars indicate significant difference $(p<0.05)$

Table 1 Water solubility, viscosity, average molecular weight (MW) and antioxidative activity of COS-L from squid pen

\begin{tabular}{ll}
\hline Water Solubility (\%) & $49.14 \pm 0.89$ \\
Viscosity $(\mathrm{dL} / \mathrm{g})$ & $0.41 \pm 0.00$ \\
Average MW $(\mathrm{kDa})$ & $78.82 \pm 2.55$ \\
Antioxidative activity & \\
DPPH radical scavenging activity ( $\mu \mathrm{mol}$ TE/g sample) & $5.68 \pm 0.36$ \\
ABTS radical scavenging activity ( $\mu \mathrm{mol}$ TE/g sample) & $322.68 \pm 8.46$ \\
FRAP ( $\mu$ mol TE/g sample) & $5.66 \pm 0.15$ \\
Metal chelating activity $(\mu \mathrm{mol}$ EE/g sample) & $2.58 \pm 0.11$ \\
ORAC ( $\mu$ mol TE/g sample) & $42.20 \pm 4.85$ \\
\hline
\end{tabular}

Values are expressed as mean \pm SD $(n=3)$. water. With the lower MW after hydrolysis by lipase, hydrogen bonding of hydroxyl group in COS produced underwent interaction or binding with water. Laokuldilok et al. (2017) also observed increased water solubility after $16 \mathrm{~h}$ hydrolysis of chitosan (DDA 80 and 90\%) using lysozyme, papain, or cellulase. However, chitosan of 90\% DDA showed higher water solubility. Higher accessibility of enzyme to substrate was presumed, resulting in the formation of COS with lower MW.

\section{Antioxidative activities}

DPPH, ABTS radical scavenging activities, FRAP, metal chelating activity and ORAC of COS-L are depicted in Table 1. COS-L had high ABTS radical scavenging activity (323 $\mu \mathrm{mol} \mathrm{TE} / \mathrm{g}$ sample). ORAC $(42 \mu \mathrm{mol} \mathrm{TE} / \mathrm{g}$ sample), FRAP $(5.7 \mu \mathrm{mol} \quad \mathrm{TE} / \mathrm{g}$ sample $)$, and $\mathrm{DPPH}$ radical 
scavenging activity $(5.7 \mu \mathrm{mol} \mathrm{TE} / \mathrm{g}$ sample) were also noted. COS-L showed metal chelating activity of $2.6 \mu \mathrm{mol}$ $\mathrm{EE} / \mathrm{g}$ sample. Free amino group of glucosamine can form ammonium group by taking a hydrogen ion from the system, which later can react with radicals (Laokuldilok et al. 2017). Additionally, more hydroxyl groups generated after hydrolysis could function as hydrogen donor to radicals. Chitosan, which has strong intra-molecular hydrogen bonding, showed lower antioxidant activity (Tomida et al. 2009). The results confirmed that COS-L with lower MW possessed higher radical scavenging activity than chitosan. Kim and Thomas (2007) stated that chitosan with MW $30 \mathrm{kDa}$ had the higher DPPH radical scavenging activity as compared to those of 90 and $120 \mathrm{kDa}$ chitosan. In present study, COS from squid pen chitosan showed both ABTS and DPPH radical scavenging activities (Table 1). ABTS radical scavenging activity assay can be used for both hydrophilic and lipophilic substances, whereas DPPH radical scavenging activity assay is applicable in the lipophilic system (Senphan \& Benjakul 2014). ORAC assay determined the oxidative degradation of the fluorescent molecule azo-initiator compounds. Azo-initiators produce the peroxyl radical by heating, which damages the fluorescent molecule, resulting in the loss of fluorescence. In the presence of COS-L, the oxidation of fluorescent molecule was lowered or terminated. Hence, COS-L had the potential to scavenge radicals, thus having an ability to prevent lipid oxidation by chain termination reaction.

FRAP assay generally determines the reducing power of antioxidant, showing the potential of substance to reduce TPTZ-Fe (III) complex to TPTZ-Fe (II) complex. Reducing power demonstrated the potential of COS- $\mathrm{L}$ to reduce $\mathrm{Fe}^{3+}$ to $\mathrm{Fe}^{2+}$ by donating electron and prevent or retard propagation step. Chitosan and COS has been known to remove various toxic metals from the aqueous environment due to the presence of reactive hydroxyl group at $\mathrm{C}-3$ and C-6 with amino group at C-2 (Zhang et al. 2016). COS can remove metal ions through different mechanisms such as chelation via lone electron pairs of amino or ion exchange of protonated amino group (Guzman et al. 2003). Huang et al. (2006) modified $\mathrm{COS}$ at amino position with carboxyl and quaternized amino groups to alter the amount of hydrogen atoms. After modification, the reduction in DPPH radical scavenging activity was observed. The results suggested the crucial role of amino group and hydroxyl groups in COS-L for its antioxidative activities.

\section{Antibacterial activity}

MIC and MBC of COS-L against targeted bacteria are presented in Table 2. MIC were 4.91, 0.62, 0.31,
Table 2 Minimum inhibitory concentration (MIC) and minimum bacterial concentration of COS-L from squid pen

\begin{tabular}{lll}
\hline Targeted microbes & $\mathrm{MIC}(\mathrm{mg} / \mathrm{mL})$ & $\mathrm{MBC}(\mathrm{mg} / \mathrm{mL})$ \\
\hline Listeria monocytogenes & $4.91 \pm 0.2$ & $4.91 \pm 0.21$ \\
Vibrio parahaemolyticus & $0.62 \pm 0.01$ & $2.46 \pm 0.2$ \\
Pseudomonas aeruginosa & $0.31 \pm 0.00$ & $0.62 \pm 0.01$ \\
Staphylococcus aureus & $4.91 \pm 0.3$ & $4.91 \pm 0.5$ \\
Salmonella enterica & $1.23 \pm 0.96$ & $2.46 \pm 1.8$ \\
\hline
\end{tabular}

Values are expressed as mean $\pm \operatorname{SD}(n=3)$.

4.91 and $1.23 \mathrm{mg} / \mathrm{mL}$ for $L$. monocytogenes, $V$. parahaemolyticus, $P$. aeruginosa, $S$. aureus and $S$. enter$i c a$, respectively. The lowest MIC value $(0.31 \mathrm{mg} / \mathrm{mL})$ was observed for $P$. aeruginosa, whereas the highest MIC value $(4.91 \mathrm{mg} / \mathrm{mL})$ was found for $L$. monocytogenes and $S$. aureus. Gram-negative bacteria were sensitive to $\mathrm{COS}-\mathrm{L}$ as indicated by lower MIC and MBC than those of Gram-positive. This was more likely due to thinner cell wall of the former (Olatunde et al. 2018). Chitosan and COS are known to possess antibacterial activity, which is influenced by the MW (No et al. 2002). Moreover, susceptibility of microorganism towards COS could be varied. Bacillus subtilis, Pseudomonas aureofaciens, Bifidobacterium bifidum 791 and Enterobacter agglomerans were resistant to chitosan with an average MW of 5 to 27 $\mathrm{kDa}$ (DDA-85\%), while Escherichia coli was more sensitive to the $5 \mathrm{kDa}$ chitosan (Gerasimenko et al. 2004). Gerasimenko et al. (2004) also reported the sensitivity of Candida krusei, S. aureus and Bifidobacterium bifidum ATCC 14893 against chitosan with different MW, which were varied between 5 and $27 \mathrm{kDa}$. Park et al. (2004) studied the effect chitosan having DDA of 90,75 and $50 \%$ and their COS of varying MWs on 32 strains of $V$. parahaemolyticus. MIC were 0.5 and $1.0 \mathrm{mg} / \mathrm{mL}$ for 14 and 18 strains, respectively. In addition, MIC of most hetero-chitosan oligosaccharides was $8.0 \mathrm{mg} / \mathrm{mL}$. Hence, COS-L with low MW could inhibit the number of bacteria, both pathogenic and spoilage bacteria.

MBC were 4.91, 2.46, $0.62,4.91,2.46 \mathrm{mg} / \mathrm{mL}$ for $L$. monocytogenes, $V$. parahaemolyticus, $P$. aeruginosa, $S$. aureus and $S$. enterica, respectively. Antibacterial effect of any substance can be assured by comparing the MBC and MIC values (Olatunde et al. 2018). The ratio of $\mathrm{MBC} / \mathrm{MIC}$ determined the bacteriostatic and bactericidal effect of the tested substances. Generally, the ratio of $\leq 2$ indicated 'bacteriostatic' effect, where ratio $>2$ reflected bactericidal impact. MBC/MIC ratio of $L$. monocytogenes, $V$. parahaemolyticus, $P$. aeruginosa, S. aureus and S. enterica were 1, 3.97, 2, 1 and 
2, respectively. Therefore, COS-L could act as bactericidal agent for $V$. parahaemolyticus, $P$. aeruginosa and $S$. enterica and possessed bacteriostatic effect towards L. monocytogenes and S. aureus.

\section{Storage stability of sardine surimi gel added without and with COS-L \\ Lipid oxidation}

PV and TBARS values of sardine surimi gel in the absence and presence of $1 \%$ COS-L from squid pen chitosan are presented in Fig. 3a and b, respectively. The increases in TBARS value were observed with increasing storage time from day 0 to 10 in both samples $(p<0.05)$. However, surimi gel without COS-L showed higher TBARS value than that of gel added with COS-L at the same storage time $(p<0.05)$. TBARS represent the secondary oxidation products in the oxidized lipid (Saeleaw et al. 2018). Similarly, PV of sardine surimi gel with and without COS-L was also increased as the storage time increased from 0 to 10 days (Fig. 3a). However, higher PV was observed for gel without COS-L than that of gel added with COS-L at the same storage time $(p<0.05)$. This was more likely due to antioxidative capacity of COS-L (Table 1). The result was in line with that for TBARS (Fig. 3 b). Lipid oxidation resulted in off-flavor and off-odor of fish muscles due to oxidative deterioration of polyunsaturated fatty acid, thereby shortening shelf-life of food (Mao \& Wu 2007). TBARS and PV values are both well-known parameters to determine lipid oxidation in the food system. Mao and $\mathrm{Wu}$

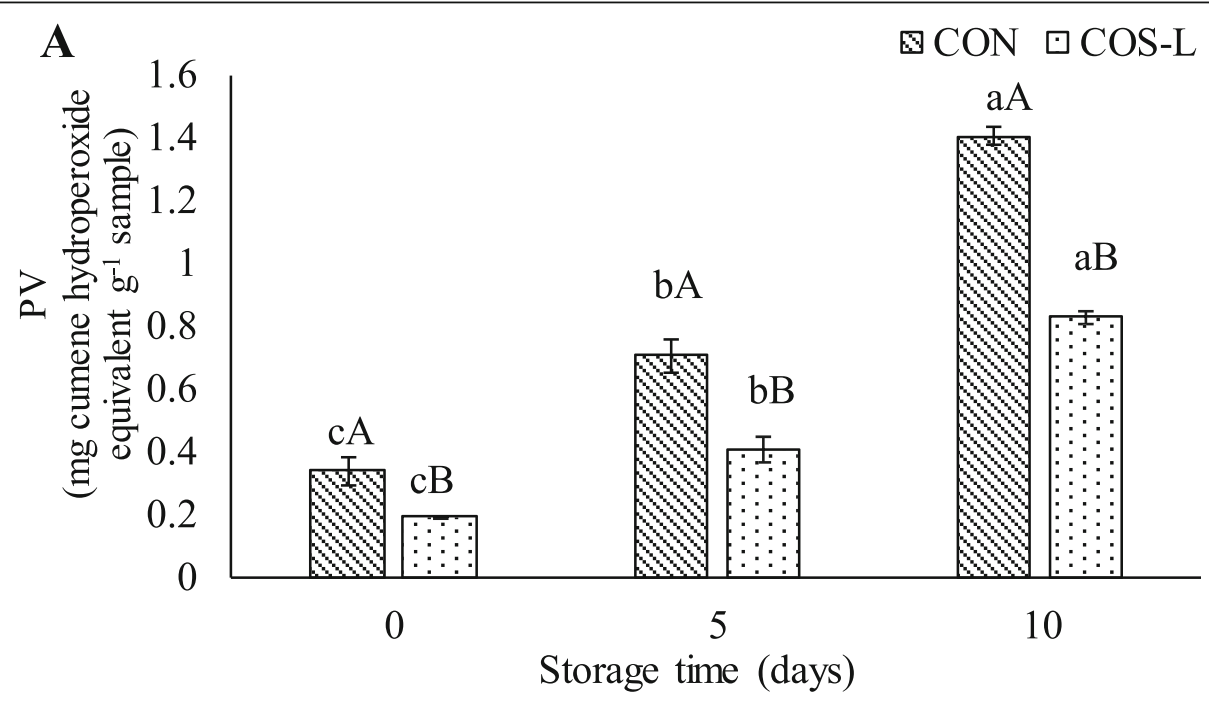

B

\& CON $\square \mathrm{COS}-\mathrm{L}$

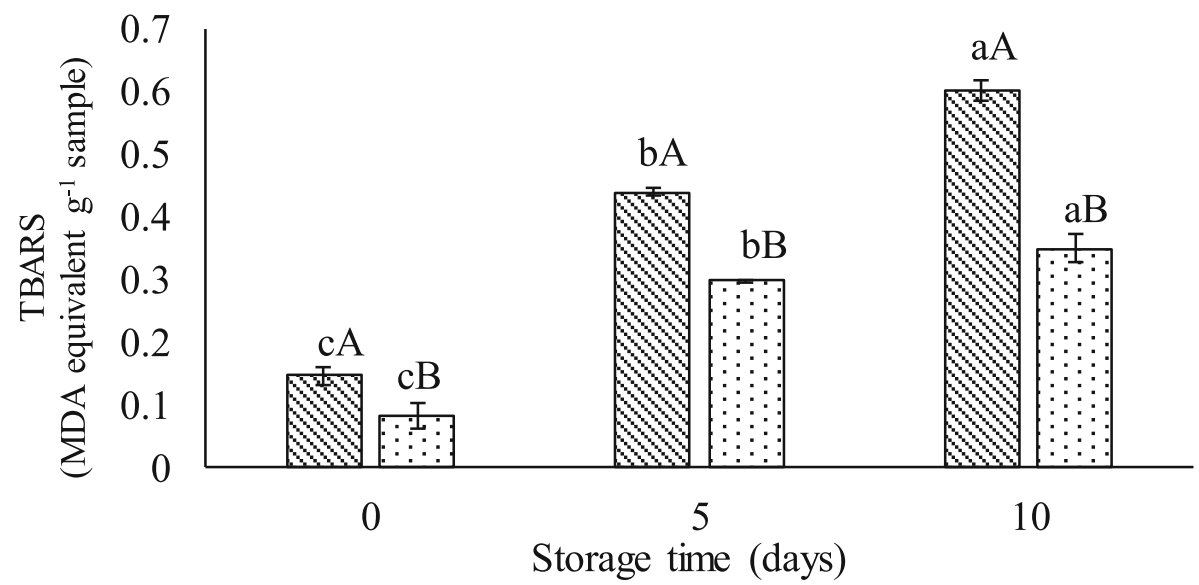

Fig. 3 Peroxide value (PV) (a) and thiobarbituric acid reactive substances (TBARS) (b) of sardine surimi gels without and with 1\% COS-L from squid pen during refrigerated storage at $4{ }^{\circ} \mathrm{C}$ for 10 days. CON: gel without addition of COS-L; COS-L: gel added with $1 \%$ COS-L. Bars represent the standard deviation $(n=3)$. Different lowercase letters on the bars within the same sample indicate significant differences $(p<0.05)$. Different uppercase letters on the bars within the same storage time indicate significant differences $(p<0.05)$ 
(2007) observed the lower PV and TBARS values in the gel from grass carp surimi incorporated with commercial chitosan with different MW. Low MW chitosan $(10 \mathrm{kDa})$ exhibited higher capacity to inhibit lipid oxidation as compared to high MW chitosan (300 kDa). Similarly, Carmen Gómez-Guillén et al. (2005) observed lower increases in TBARS and PV values of gel from horse mackerel surimi when $1 \%$ chitosan from shrimp shells (DDA-97\%) was incorporated. Antioxidative activities of COS-L was more likely due to its radical scavenging and metal binding capacities (Table 1). Fish tissue, particularly dark fleshed fish, e.g. sardine etc., contains iron bound to the protein, which could be released during heat induced gelation. Free iron could act as prooxidant and accelerated lipid oxidation (St. Angelo et al. 1996). COS-L might chelate ferrous ions from the system, thus retarding lipid oxidation. Furthermore, amino group at $\mathrm{C}-2$ might participate in metal chelation (Mao \& Wu 2007). Therefore, the addition of COS-L into sardine surimi gel could retard lipid oxidation during the extended storage at $4{ }^{\circ} \mathrm{C}$.

\section{Microbial load}

TVC, PBC, TFC, Enterobacteriaceae and Pseudomonas counts of sardine surimi gel added without and with $1 \%$ COS-L during storage at $4{ }^{\circ} \mathrm{C}$ are depicted in Table 3 . All initial counts of gel without and with COS-L addition were in the range of 2.28-3.24 and 1.07-1.51 $\log \mathrm{CFU} / \mathrm{g}$, respectively. Higher counts of all microorganism tested were observed in the control gel as compared to the gel added with COS-L at the same storage time $(p<0.05)$. Psychrophilic bacteria and Pseudomonas were not found in gel added with COS-L $(<1 \log$ $\mathrm{CFU} / \mathrm{g}$ sample) at day 0 . At day 10 , all counts were in the range of 5.49-6.57 and 3.18-4.77 log CFU/g sample for gels added without and with COS-L, respectively. The result showed significant reduction in counts of surimi gel in the presence of COS-L during 10 days of storage. This was more likely due to the antimicrobial capacity of COS-L (Table 2). Amiza and Kang (2013) studied the effect of food grade chitosan (MW-10 kDa, DDA-95\%) on gel from catfish surimi. Gels added with $2 \%$ chitosan showed lower microbial counts than control gel $\quad(p<0.05)$ during storage at $4{ }^{\circ} \mathrm{C}$. In general, antimicrobial activity of COS was more likely due the inhibition of mRNA and protein translation. Chelation of essential nutrients and metals are the known mechanisms advocating antimicrobial activity of COS. No et al. (2002) reported that COS from crab shell with MW of 1 $\mathrm{kDa}$ showed the higher antimicrobial activity against Gram-negative bacteria, while those having MW of 4 and $2 \mathrm{kDa}$ exhibited high activity towards Gram-positive bacteria. COS from exoskeletons of marine crustaceans (1\%) inactivated 4.5 and $0.5 \log \mathrm{CFU} / \mathrm{g}$ of Actinobacillus actinomycetemcomitans and Streptococcus mutans, respectively after $120 \mathrm{~min}$ of exposure (Choi et al. 2001). For antifungal activity, COS might penetrate into fungal cell and caused structural and molecular changes in the cells (Younes et al. 2014). Younes et al. (2014) reported that commercially available chitosan with varying DDAs and MWs retarded the growth of food spoilage microbes such as Aspergillus niger, Fusarium oxysporum and Alternaria solani. Hence, COS-L successfully inhibited the growth of microorganisms in sardine surimi gel during the refrigerated storage of 10 days.

\section{Conclusion}

Chitooligosaccharide (COS) produced from squid pen chitosan using lipase named COS-L showed the highest antioxidative activity as compared to those prepared using amylase and pepsin. COS-L had medium MW and showed improved solubility in water. Addition of $1 \%$ COS-L could lower lipid oxidation in sardine surimi gel during refrigerated storage as shown by the decreased PV and TBARS values. COS-L also suppressed the growth of spoilage bacteria Pseudomonas and Enterobacteriaceae as well as fungus in surimi gel during the refrigerated storage. Thus, COS-L from squid pen could increase the shelf-life of sardine surimi gel kept at refrigerated temperature.

Table 3 Microbial counts of sardine surimi gel added without and with $1 \%$ COS-L from squid pen

\begin{tabular}{|c|c|c|c|c|c|c|}
\hline \multirow[t]{2}{*}{ Samples } & \multirow{2}{*}{$\begin{array}{l}\text { Storage } \\
\text { time } \\
\text { (days) }\end{array}$} & \multicolumn{5}{|c|}{ Microbial load log CFU/g } \\
\hline & & TVC & PBC & TFC & Enterobacteriaceae count & Pseudomonas count \\
\hline \multirow[t]{3}{*}{ CON } & 0 & $3.24 \pm 0.01^{c}$ & $2.28 \pm 0.02^{c}$ & $2.96 \pm 0.01^{c}$ & $2.69 \pm 0.03^{c}$ & $2.98 \pm 0.06^{c}$ \\
\hline & 5 & $4.62 \pm 0.04^{b}$ & $5.20 \pm 0.02^{b}$ & $5.41 \pm 0.03^{b}$ & $4.30 \pm 0.03^{b}$ & $4.58 \pm 0.06^{b}$ \\
\hline & 10 & $5.94 \pm 0.06^{a}$ & $6.57 \pm 0.03^{a}$ & $5.55 \pm 0.02^{\mathrm{a}}$ & $5.49 \pm 0.04^{\mathrm{a}}$ & $5.88 \pm 0.01^{\mathrm{a}}$ \\
\hline \multirow[t]{3}{*}{ COS-L } & 0 & $1.32 \pm 0.03^{c}$ & ND & $1.51 \pm 0.01^{c}$ & ND & $1.07 \pm 0.03^{c}$ \\
\hline & 5 & $2.48 \pm 0.04^{b}$ & $2.30 \pm 0.04^{b}$ & $2.39 \pm 0.03^{b}$ & $1.90 \pm 0.09^{b}$ & $2.20 \pm 0.04^{b}$ \\
\hline & 10 & $3.75 \pm 0.02^{\mathrm{a}}$ & $4.77 \pm 0.03^{\mathrm{a}}$ & $3.79 \pm 0.05^{\mathrm{a}}$ & $3.18 \pm 0.06^{\mathrm{a}}$ & $3.62 \pm 0.04^{\mathrm{a}}$ \\
\hline
\end{tabular}

Values are expressed as mean \pm SD $(n=3)$. CON: gel without addition of COS-L; COS-L: gel added with $1 \%$ (w/w) COS-L. Different lowercase superscripts within the same sample in the same column indicate significant differences $(p<0.05)$ ND Not detected 


\section{Abbreviations}

AAPH: 2,2'-azobis (2-methylpropionamidine) dihydrochloride; ABTS: 2,2-azinobis (3-ethylbenzothiazoline-6-sulphonic acid); CFU: Colony forming unit; COS: Chitooligosaccharides; COS-L: COS produced using lipase; DDA: Degree of deacetylation; DDP: Degrees of depolymerization; DPPH: 2,2-diphenyl-1picrylhydrazyl; EDTA: Ethylenediaminetetraacetic acid; EE: EDTA equivalent; FRAP: Ferric reducing antioxidant power; kDa: Kilodalton; MBC: Minimum bactericidal concentration; MIC: Minimum inhibitory concentration; MW: Molecular weight; ORAC: Oxygen radical absorbance capacity; PBC: Psychrophilic bacterial count; PV: Peroxide value; TBARS: Thiobarbituric acid reactive substances; TE: Trolox equivalent; TFC: Total fungal count; TPTZ: 2,4,6-tripyridyltriazine; TSB: Tryptic soy broth; TVC: Total viable count

\section{Acknowledgments}

This research was supported by the Higher Education Research Promotion and the Thailand's Education Hub for Southern Region of ASEAN Countries (THE-AC, 2015) scholarship and Graduate School, Prince of Songkla University.

\section{Authors' contributions}

SB and AS designed the experiment. The experiment and data compilation were conducted by AS and data analysis was done by SB and TP. AS wrote the manuscript. SB and TP critically revised the manuscript. All authors read and approved the final manuscript.

\section{Funding}

None.

\section{Availability of data and materials}

Not acceptable.

\section{Competing interests}

The authors declare that they have no competing interests.

\section{Author details}

${ }^{1}$ Department of Food Technology, Faculty of Agro-Industry, Prince of Songkla University, Hat Yai, Songkhla 90110, Thailand. ${ }^{2}$ Department of Material Product Technology, Faculty of Agro-Industry, Prince of Songkla University, Hat Yai, Songkhla 90110, Thailand.

\section{Received: 15 April 2019 Accepted: 10 September 2019}

\section{Published online: 28 October 2019}

\section{References}

Amiza, M., \& Kang, W. (2013). Effect of chitosan on gelling properties, lipid oxidation, and microbial load of surimi gel made from African catfish (Clarias gariepinus). International Food Research Journal, 20, 1585.

Benjakul, S., Kittiphattanabawon, P., Sumpavapol, P., \& Maqsood, S. (2014). Antioxidant activities of lead (Leucaena leucocephala) seed as affected by extraction solvent, prior dechlorophyllisation and drying methods. Journal of Food Science and Technology, 51, 3026-3037.

Buamard, N., \& Benjakul, S. (2017). Ethanolic coconut husk extract: In vitro antioxidative activity and effect on oxidative stability of shrimp oil emulsion. European Journal of Lipid Science and Technology, 119, 1700131.

Carmen Gómez-Guillén, M., Montero, P., Teresa Solas, M., \& Pérez-Mateos, M. (2005). Effect of chitosan and microbial transglutaminase on the gel forming ability of horse mackerel (Trachurus spp.) muscle under high pressure. Food Research International, 38, 103-110.

Choi, B.-K., Kim, K.-Y., Yoo, Y.-J., Oh, S.-J., Choi, J.-H., \& Kim, C.-Y. (2001). In vitro antimicrobial activity of a chitooligosaccharide mixture against Actinobacillusactino mycetemcomitans and Streptococcus mutans. International Journal of Antimicrobial Agents, 18, 553-557.

Dubois, M., Gilles, K. A., Hamilton, J. K., Rebers, P., \& Smith, F. (1956). Colorimetric method for determination of sugars and related substances. Analytical Chemistry, 28, 350-356.

Elieh-Ali-Komi, D., \& Hamblin, M. R. (2016). Chitin and chitosan: Production and application of versatile biomedical nanomaterials. International Journal of Advanced Research, 4, 411-427.

Fernandes, J. C., Tavaria, F. K., Soares, J. C., Ramos, Ó. S., Monteiro, M. J., Pintado, M. E., et al. (2008). Antimicrobial effects of chitosans and chitooligosaccharides, upon Staphylococcus aureus and Escherichia coli, in food model systems. Food Microbiology, 25, 922-928.

Gerasimenko, D. V., Avdienko, I. D., Bannikova, G. E., Zueva, O., \& Varlamov, V. P. (2004). Antibacterial effects of water-soluble low-molecular-weight chitosans on different microorganisms. Prikladnaia Biokhimiia $i$ Mikrobiologiia, 40, 301-306.

Gohi, B. F. C. A., Zeng, H.-Y., Pan, A. D., Han, J., \& Yuan, J. (2017). pH dependence of chitosan enzymolysis. Polymers, 9, 174.

Guzman, J., Saucedo, I., Revilla, J., Navarro, R., \& Guibal, E. (2003). Copper sorption by chitosan in the presence of citrate ions: Influence of metal speciation on sorption mechanism and uptake capacities. International Journal of Biological Macromolecules, 33, 57-65.

Huang, R., Rajapakse, N., \& Kim, S.-K. (2006). Structural factors affecting radical scavenging activity of chitooligosaccharides (COS) and its derivatives. Carbohydrate Polymers, 63, 122-129.

Il'Ina, A., \& Varlamov, V. (2004). Hydrolysis of chitosan in lactic acid. Applied Biochemistry and Microbiology, 40, 300-303.

Je, J.-Y., Park, P.-J., \& Kim, S.-K. (2004). Free radical scavenging properties of hetero-chitooligosaccharides using an ESR spectroscopy. Food and Chemical Toxicology, 42, 381-387.

Kim, K. W., \& Thomas, R. L. (2007). Antioxidative activity of chitosans with varying molecular weights. Food Chemistry, 101, 308-313.

Laokuldilok, T., Potivas, T., Kanha, N., Surawang, S., Seesuriyachan, P., Wangtueai, S. , et al. (2017). Physicochemical, antioxidant, and antimicrobial properties of chitooligosaccharides produced using three different enzyme treatments. Food Bioscience, 18, 28-33.

Lee, C., Shin, S., \& Lee, Y. (2007). Degradation of chitosan with the aid of lipase from Rhizopus japonicus for the production of soluble chitosan. Journal of Food Biochemistry, 25, 307-321.

Lee, D.-X., Xia, W.-S., \& Zhang, J.-L. (2008). Enzymatic preparation of chitooligosaccharides by commercial lipase. Food Chemistry, 111, 291-295.

Liagat, F., \& Eltem, R. (2018). Chitooligosaccharides and their biological activities: A comprehensive review. Carbohydrate Polymers, 184, 243-259.

Lodhi, G., Kim, Y.-S., Hwang, J.-W., Kim, S.-K., Jeon, Y.-J., Je, J.-Y., et al. (2014). Chitooligosaccharide and its derivatives: Preparation and biological applications. BioMed Research International, 2014, 654913.

Mao, L., \& Wu, T. (2007). Gelling properties and lipid oxidation of kamaboko gels from grass carp (Ctenopharyngodon idellus) influenced by chitosan. Journal of Food Engineering, 82, 128-134.

Miller, G. L. (1959). Use of dinitrosalicylic acid reagent for determination of reducing sugar. Analytical Chemistry, 31, 426-428.

Mourya, V., Inamdar, N., \& Choudhari, Y. M. (2011). Chitooligosaccharides: Synthesis, characterization and applications. Polymer Science Series A, 53, 583-612.

No, H. K., Young Park, N., Ho Lee, S., \& Meyers, S. P. (2002). Antibacterial activity of chitosans and chitosan oligomers with different molecular weights. International Journal of Food Microbiology, 74, 65-72.

Olatunde, O. O., Benjakul, S., \& Vongkamjan, K. (2018). Antioxidant and antibacterial properties of guava leaf extracts as affected by solvents used for prior dechlorophyllization. Journal of Food Biochemistry. https://doi.org/10.1111/jfbc.12600.

Pan, S., \& Wu, S. (2011). Preparation of water-soluble chitosan by hydrolysis with commercial glucoamylase containing chitosanase activity. European Food Research and Technology, 233, 325-329.

Park, P.-J., Lee, H.-K., \& Kim, S.-K. (2004). Preparation of heterochitooligosaccharides and their antimicrobial activity on Vibrio parahaemolyticus. Journal of Microbiology and Biotechnology, 14, 41-47.

Piper, D., \& Fenton, B. H. (1965). pH stability and activity curves of pepsin with special reference to their clinical importance. Gut, 6, 506-508.

Quan, T. H., \& Benjakul, S. (2017). Comparative study on the effect of duck and hen egg albumens on proteolysis and gel property of sardine surimi. International Journal of Food Properties, 20, S2786-S2S97.

Rahman, M. H., Hjeljord, L. G., Aam, B. B., Sørlie, M., \& Tronsmo, A. (2015). Antifungal effect of chito-oligosaccharides with different degrees of polymerization. European Journal of Plant Pathology, 141, 147-158.

Rokhati, N., Widjajanti, P., Pramudono, B., \& Susanto, H. (2013). Performance comparison of a-and $\beta$-amylases on chitosan hydrolysis. ISRN Chemical Engineering, 2013, 1-5.

Roncal, T., Oviedo, A., de Armentia, I. L., Fernández, L., \& Villarán, M. C. (2007). High yield production of monomer-free chitosan oligosaccharides by pepsin catalyzed hydrolysis of a high deacetylation degree chitosan. Carbohydrate Research, 342, 2750-2756.

Sae-leaw, T, Buamard, N., Vate, N. K, \& Benjakul, S. (2018). Effect of squid melanin-free ink and pre-emulsification on properties and stability of surim 
gel fortified with seabass oil during refrigerated storage. Journal of Aquatic Food Product Technology, 27, 919-933.

Sallam, K. I. (2007). Chemical, sensory and shelf life evaluation of sliced salmon treated with salts of organic acids. Food Chemistry, 101, 592-600.

Senphan, T., \& Benjakul, S. (2014). Antioxidative activities of hydrolysates from seabass skin prepared using protease from hepatopancreas of Pacific white shrimp. Journal of Functional Foods, 6, 147-156.

Singh, A., \& Benjakul, S. (2017a). Effect of serine protease inhibitor from squid ovary on gel properties of surimi from Indian mackerel. Journal of Texture Studies, 54, 541-549.

Singh, A., \& Benjakul, S. (2017b). Serine protease inhibitors from squid ovary: Extraction and its effect on proteolysis and gel properties of surimi. Journal of Food Science and Technology, 54, 267-275.

Singh, A., \& Benjakul, S. (2018). Proteolysis and its control using protease inhibitors in fish and fish products: A review. Comprehensive Reviews in Food Science and Food Safety, 17, 496-509.

Singh, A., Benjakul, S., \& Prodpran, T. (2019a). Ultrasound-assisted extraction of chitosan from squid pen: Molecular characterization and fat binding capacity. Journal of Food Science, 84, 224-234

St. Angelo, A. J., Vercellotti, J., Jacks, T., \& Legendre, M. (1996). Lipid oxidation in foods. Critical Reviews in Food Science and Nutrition, 36, 175-224.

Steel, R. G. D., \& Torrie, J. H. (1986). Principles and procedures of statistics: A biometrical approach. McGraw-Hill.

Tomida, H., Fujii, T., Furutani, N., Michihara, A., Yasufuku, T., Akasaki, K., et al. (2009). Antioxidant properties of some different molecular weight chitosans. Carbohydrate Research, 344, 1690-1696.

Tongnuanchan, P., Benjakul, S. \& Prodpran, T. (2012). Properties and antioxidant activity of fish skin gelatin film incorporated with citrus essential oils. Food Chemistry, 134, 1571-1579.

Vanderzant, C., \& Splittstoesser, D. F. (1992). Compendium of methods for the microbiological examination of foods. 3rd Edition. American Public Health Association, Washington, DC.

Wu, S. (2011). Preparation of water soluble chitosan by hydrolysis with commercial a-amylase containing chitosanase activity. Food Chemistry, 128, 769-772.

Xie, W., Xu, P., \& Liu, Q. (2001). Antioxidant activity of water-soluble chitosan derivatives. Bioorganic and Medicinal Chemistry Letters, 11, 1699-1701.

Yacob, N., Talip, N., Mahmud, M., Sani, N., Samsuddin, N., \& Fabillah, N. (2013). Determination of viscosity-average molecular weight of chitosan using intrinsic viscosity measurement. Journal of Nuclear and Related Technologies, 10, 39-44.

Younes, I., Sellimi, S., Rinaudo, M., Jellouli, K., \& Nasri, M. (2014). Influence of acetylation degree and molecular weight of homogeneous chitosans on antibacterial and antifungal activities. International Journal of Food Microbiology, 185, 57-63.

Zhang, L., Zeng, Y., \& Cheng, Z. (2016). Removal of heavy metal ions using chitosan and modified chitosan: A review. Journal of Molecular Liquids, 214, 175-191.

Singh, A., Benjakul, B., \& Prodpran, T. (2019b). Effect of chitooligosaccharide from squid pen on gel properties of sardine surimi gel and its stability during refrigerated storage. International Journal of Food Science and Technology. https://doi.org/10.1111/ijfs.14199.

\section{Publisher's Note}

Springer Nature remains neutral with regard to jurisdictional claims in published maps and institutional affiliations.

Ready to submit your research? Choose BMC and benefit from:

- fast, convenient online submission

- thorough peer review by experienced researchers in your field

- rapid publication on acceptance

- support for research data, including large and complex data types

- gold Open Access which fosters wider collaboration and increased citations

- maximum visibility for your research: over $100 \mathrm{M}$ website views per year

At $\mathrm{BMC}$, research is always in progress.

Learn more biomedcentral.com/submissions 